\title{
低電力ホールスラスタの基本作動特性と推進性能*1 Basic Operational Characteristics and Thrust Performance of Low Power Hall Thrusters
}

\author{
田 原 弘 - $^{* 2} \cdot$ 後 藤 大 亮*2 $\cdot$ 藤 岡 崇 志*2 $\cdot$ 北 野 貴 久*2 \\ Hirokazu Tahara, Daisuke Goto, Takashi Fujioka, Takahisa Kitano, \\ 白 崎 篤 司*2. 安井利 明*2.吉 川 孝 雄*2 \\ Atsushi Shirasaki, Toshiaki Yasui and Takao YoshikawA
}

Key Words : Space Propulsion, Electric Propulsion, Hall Thruster, Operational Characteristics, Thrust Performance

\begin{abstract}
Laboratory-model low-power Hall thrusters, named the THT-III-series, were operated in order to examine influences of ceramics species of the acceleration channel walls, and shape and strength of radial magnetic field in the acceleration channels on the operational characteristics. For the THT-III A-BN thruster both with acceleration channel walls made of boron nitride and with more intensive concentration of magnetic field lines near the acceleration channel exit, a higher thrust efficiency was achieved with a lower discharge current and a higher thrust for an optimum magnetic field strength regardless of discharge voltage at a constant xenon mass flow rate. Accordingly, both the thrust and the specific impulse ranged from 10 to $70 \mathrm{mN}$ and from 1,200 to $2,300 \mathrm{~s}$, respectively, at discharge voltages of $200-500 \mathrm{~V}$ with mass flow rates of $1-3 \mathrm{mg} / \mathrm{s}$ in a wide input power range of $250-1,800 \mathrm{~W}$. The thrust efficiency ranged from 30 to $45 \%$.
\end{abstract}

\section{1. ま え がき}

ホールスラスタは円環状の加速チャンネル内に径方向の 磁場と軸方向の電場を印加した構造であり, 下流の陰極よ り放出された電子はチャンネル内に入射し, 磁場との相互 作用 $(\mathrm{E} \times \mathrm{B}$ ドリフトにより周方向に回転する) によりチャ ンネル内に閉じ込められ，効率よくプラズマを生成する.生 成されたプラズマ中の正イオンは陽極と陰極の間の電位差 により下流に向かって静電的に加速される. 電磁流体力学 的には, 誘起された周方向ホール電流と径方向磁場の相互 作用によるローレンツカで生成プラズマか軸方向に加速さ れると見なせる . ホールスラスタは比較的コンパクトであ り，直流アークジェットスラスタよりも高い比推力 $(1,500$ 秒）と推進効率 $(50 \%)$ ，またイオンスラスタよりも高い推 力密度 (約 $1 \mathrm{mN} / \mathrm{cm}^{2}$ ) を実現しており，この 20 年ほどの 間にロシアでは数十機の衛星に SPT (Stationary Plasma Thruster) 100 と呼ばれるホールスラスタが搭載・運用さ れてきた1). 近年は欧米諸国でも地球近傍ミッションへの 適用を目的として開発, 商業化が進められている ${ }^{2,3)}$.

しかしながら，ホールスラスタのプラズマ生成・加速過 程, 噴出プルーム状態などについて未解明の問題が多く存 在し, 明確な設計指針はまだ得られていない4 12). 大阪大 学ではこれまで低電力 ( $1 \mathrm{~kW}$ 級) のホールスラスタの開発 を目指し, 実験室モデルのスラスタ, THT シリーズを試作

\footnotetext{
*1 (C) 2002 日本航空宇宙学会

平成 13 年 11 月 21 日原稿受理

*2 大阪大学大学院基礎工学研究科システム人間系専攻機械科学分野
}

し作動実験を行ってきた ${ }^{9 \sim 11)}$. 兴の 1,2 号機では加速チャ ンネル内に主に一樣な磁場を印加し, 磁場強度やムライト 系セラミックス製チャンネルの形状 (長さ, 幅) の変化が 推進性能に及ぼす影響を調べてきた . 谷の結果, 最大推進 効率は $35 \%$ 程度であり，加速チャンネル壁の材質とチャン ネル内の磁場形状の変更が推進性能の改善のためには必要 であることがわかった ${ }^{12)}$.

そこで本研究では, 3 号機 THT-III ホールスラスタを製 作し, 加速チャンネル壁の材質とチャンネル内の磁場の形 状・強さが作動特性に与える影響を調べた . チャンネル壁の セラミックスとしてムライトとボロンナイトを用い, チャ ンネル内の磁場形状としてチャンネル出口付近に磁力線を 集中させこの付近でのみ磁場を強くした . 推進剂キセノン の流量, 放電電圧, 磁場強度を変化させて放電電流と推力 を測定し，比推力と推進効率を評価した。

\section{2. 実験装置と測定方法}

2.1 ホールスラスタ作動システム ホールスラスタの 実験装置システムの概略図を第 1 図に示す. 水冷ジャケッ 卜式真空タンクの長さは $2.25 \mathrm{~m}$, 直径は $1.2 \mathrm{~m}$ であり, 2 台のターボ分子ポンプ (総排気速度 $10,000 \mathrm{l} / \mathrm{s}$ ) が接続さ れ, タンク内を高真空かつクリーンな状態に保つことがで きる . 本実験におけるスラスタ作動時の真空タンク圧力は $10^{-3} \mathrm{~Pa}$ 台である .

ホールスラスタは振り子型スラストスタンドに設置され， 作動時のスラストスタンドの変位が非接触変位計で測定さ れ推力が評価される . 推力の較正は真空環境下で約 $1 \mathrm{~g}$ の 


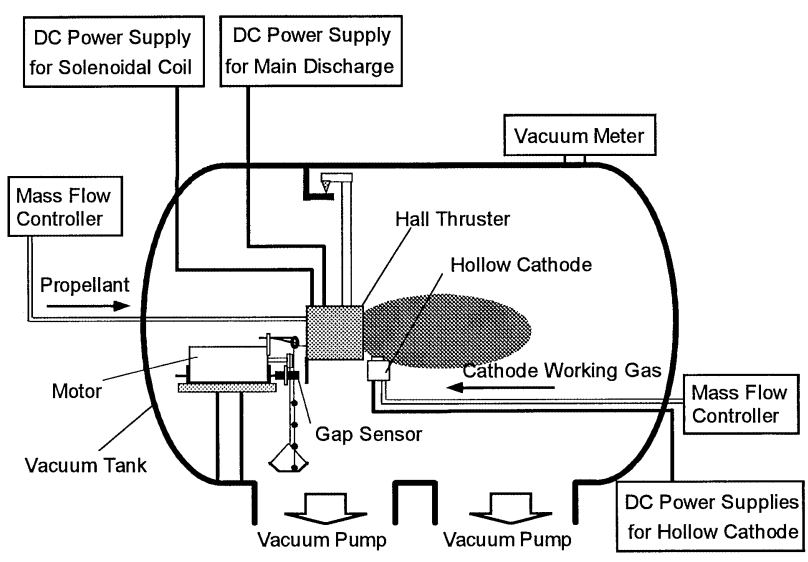

第 1 図 ホールスラスタ実験装置システムの概略図

おもりをモータを用いて1つずつ受け㿼に載せ , スラスタ に負荷していくことにより行われる . 推力較正は推力 0 $70 \mathrm{mN}$ の範囲で行われる. $50 \mathrm{mN}$ 時に $\pm 1 \mathrm{mN}$ 程度の精度 を維持していることが, 複数回行った作動実験の結果から 確かめられている.スラスタ本体には, 主放電, 磁気コイル 用，ホローカソードにはヒーター，キーパー，イグニッショ ン用の電源が接続されている. 主放電以外で消費される電 力は磁気コイルに最大 $20 \mathrm{~W}$ ，ホローカソードのキーパーに $1 \sim 2 \mathrm{~W}$ と炎のヒーターに $30 \mathrm{~W}$ (作動時) (100W (予熱 時))である .

推進剂およびホローカソードの作動ガスとしてキセノン が使用され，2 台のマスフローコントローラーによって关れ らの流量が独立して制御される.推進剂とカソード作動ガ

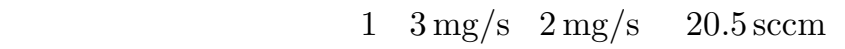
1.47 Aeq に相当)，0.1 mg/s である。

放電は 10 分程度ホローカソードを余熱した後, 推進剤お よびカソード作動ガスを流し電極間に電圧 $200 \mathrm{~V}$, 加速チャ ンネル内に磁場 100 Gauss $(0.01 \mathrm{~T})$ 程度印加した状態で， カソード電位 (陽極接地) を瞬間的に $500 \mathrm{~V}$ 程度下げると 開始する . 点火後に放電電圧とコイル電流を所定の值に設 定し, 放電電流と推力を測定する。

2.2 ホールスラスタ THT-III シリーズ 本研究では 2 種類の実験用ホールスラスタ, THT-III と THT-III A を 用いた . THT-III A の断面図を第 2 図に示す. THT-III は THT-III A の磁気シールドを取り除いたスラスタであ る.セラミックス製加速チャンネルの外径は $70 \mathrm{~mm}$, 内径 $42 \mathrm{~mm}$ であり (幅 $14 \mathrm{~mm}$ ), 弚の長さ (陽極からチャンネ ル出口まで) ( $35 \mathrm{~mm}$ である . チャンネル壁の材料として ムライト系セラミックス ((株) ニッカトー製 NC Mullite $\left.\left(\mathrm{Al}_{2} \mathrm{O}_{3}: 47 \% ; \mathrm{SiO}_{2}: 49 \%\right)\right)$ とボロンナイトライドセ ラミックス ( (株) 昭和電工製 UHS-FL (窒化硼素焼結体 (BN)：99.5\%以上)) の2 種類を用いた . 推進剂は図の左 側 4 力所から流入し , テフロン部と陽極で構成されたプレ ナム部で周方向に一樣に広がり，陽極にあけられた 24 個の 穴から加速チャンネル内に供給される . 中心部に 1 個と外 周部に 4 個の磁気コイルがあり，第 3 図に示されるように

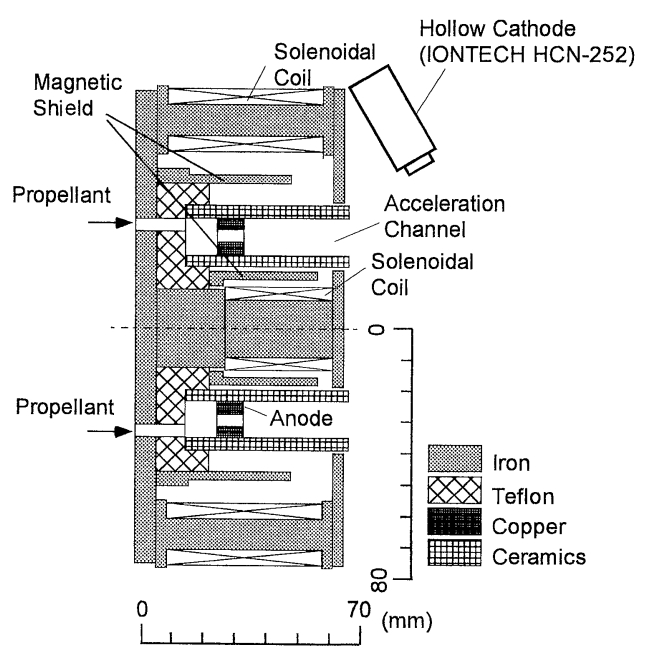

第 2 図 ホールスラスタ THT-III A の断面図

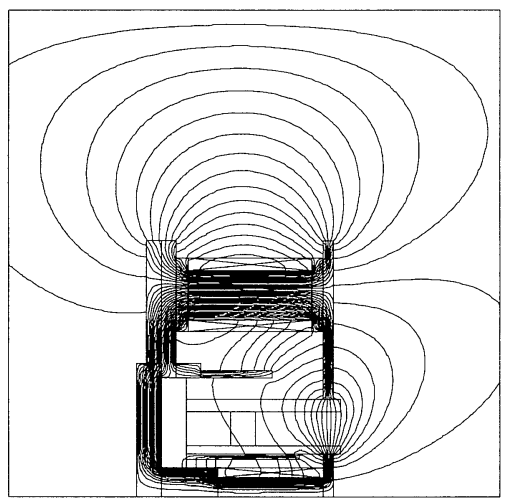

第3図＼cjkstart計算された THT-III A の磁力線プロフィール

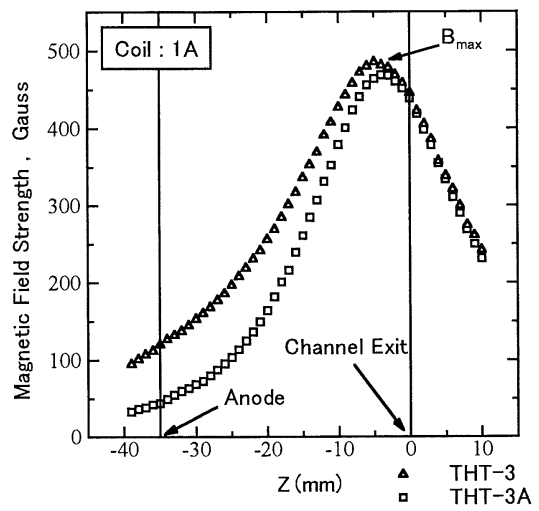

第 4 図 THT-III シリーズの加速チャンネル両壁の中間点における径 方向磁束密度の軸方向分布 (微小ホールセンサーによる測定 , 磁気コイル電流：1 A)

磁気回路が形成されており加速チャンネル内に径方向の磁 場が生み出される。

加速チャンネル両壁の中間点における径方向磁束密度の 軸方向分布を第 4 図に示す. チャンネル出口付近において 磁束密度が大きく陽極に近づくにつれて小さくなる.こう して，チャンネル出口付近でプラズマを生成・加速させるこ とによって , チャンネル壁面上でのイオン粒子・エネルギー 


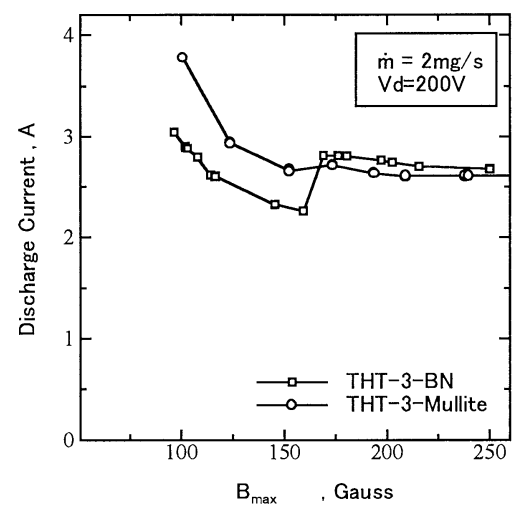

(a) 加速チャンネル壁の材質の影響 (THT-III-BN と THT-III-Mullite の比較)

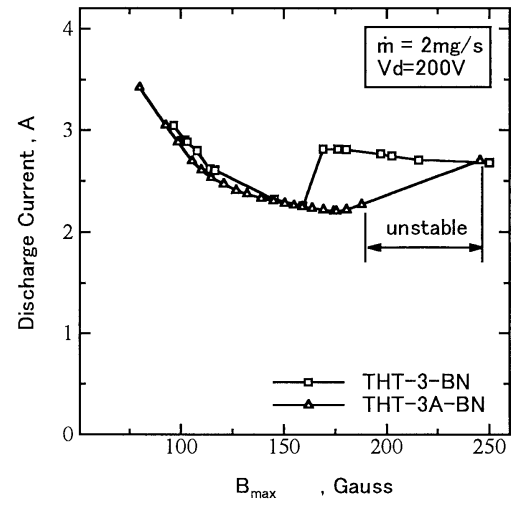

(b) 加速チャンネル内の磁場形状の影響 (THT-III-BN と THT-III A-BN の比較)

第 5 図 放電電流と磁場密度 $B_{\max }$ の関係 (推進㓢質量流量 : $2 \mathrm{mg} / \mathrm{s}$; 放電電流 : $200 \mathrm{~V}$ )

損失を低減させる方針をとる．また，スラスタ THT-III A の磁場は磁気シールドの効果により THT-III の兰れに比 ベて，よりチャンネル出口付近に磁力線が集中した，急峻 な形状をもつ . THT-III A のチャンネル出口付近の最大磁 束密度はTHT-IIIの光れとほぼ同じであるが (この最大値 を $B_{\max }$ と定義する)，乥れ以外のチャンネル内の領域で は THT-III A の磁場がTHT-III の兰れよりかなり小さい . 陽極付近では 3 分の 1 程度である.

陰極にはイオンテック社製ホローカソード HCN-252 を 使用した .すべての作動条件において十分なエミッション 電流が確保されることが確かめられている.

\section{3. 実験結果と 検討}

測定された放電電流と推力より比推力と推進効率が見積 もられた . 兴の際, ホローカソードの作動ガス流量とホロー カソードおよび磁気コイルで消費される電力はスラスタ本 体の弚れらと比較して小さいことから考慮しなかった .

3.1 加速チャンネル壁材質および磁場形状・強度の影響 放電電流と磁束密度 $B_{\max }$ の関係を第 5 図に示す. 推進剂

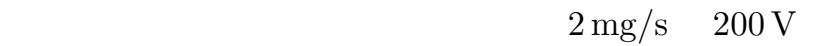
ある．全体的な傾向として，磁場か強くなるにつれて放電 電流は減少するが, 弚の減少割合は小さくなっていく. 特
に $B_{\max }$ が約 150 Gauss より大きい領域では放電電流はほ とんど一定になる．これは磁力線を横切る方向（軸方向） の電子の拡散メカニズムが変化するためと考えられる．す なわち，弱い磁場ではチャンネルバルク空間における古典 拡散が支配的であるが，磁場が強くなるにしたがってボー 厶拡散の影響か強くなると推定される、磁場が十分強くな るとバルク空間での電気伝導は激減し，チャンネル壁によ る電子の散乱 (壁近傍の電気伝導) が支配的になると予想 される (但し , チャンネル壁近傍の電気伝導の物理はほと んどわかってはいない) .

加速チャンネル材質による变化を比較すると，第 5 図 (a) より $B_{\max }$ が 100 から 150 Gauss 付近までは, ムライトを 用いた THT-III-Mullite の放電電流が BN を用いた THTIII-BN の弚れより大きい . これはチャンネル壁近傍の電気 伝導がムライトと BN とで異なるためと考えられる . また ， THT-III-BN では $B_{\max } 160$ Gauss 付近で急激な放電電流 の増加が見られ，光れよりも強い磁場では材質の違いによ る放電電流の差異がほとんど見られなくなる .これより， 160 Gauss 以上の強磁場ではチャンネル壁の材質によらな い別の電気伝導現象が支配的になっていると予想される . 磁場形状の違いによる変化を比較すると，第 5 図 (b) よ り THT-III A-BN の放電電流は $B_{\max } 160$ Gauss より強 い磁場領域においても THT-III-BN で見られるような放 電電流の大幅な上昇が起こらない，光して THT-III A-BN では 175 Gauss 程度まで放電電流はわずかに低下していく が，乥れを超えると放電が不安定になり，放電電流は一気 に THT-III-BN の兰れまで上昇する.弱磁場域では放電電 流波形に電離不安定性に起因すると推定される $20 \mathrm{kHz}$ の 振動か現れるが , 磁場が大きくなるにつれてこの振動の振 幅は小さくなり，放電が不安定になる条件ではこの振動は 全く消えてしまう. 放電の不安定現象の原因は不明である が, この電離不安定性やさらなる高周波振動を伴うプラズ マ中の不安定現象に関係していると推測される ${ }^{4)}$. 以上よ り，加速チャンネル出口付近に磁力線を集中させ磁場を強 く，陽極付近における磁場を弱くすることによって，安定 作動が可能な磁場の範囲が広がり, 弚の結果放電電流をよ り小さくできることがわかった .

推力・比推力と磁束密度 $B_{\max }$ の関係を第 6 図に示す. THT-III-Mullite の推力・比推力は THT-III-BN の乥れら と全く同じであり，加速チャンネルの材質による影響を受 けないことがわかった .

磁場力溞くなるとき，THT-III-BN の推力・比推力はほと んど一定であるが，THT-III A-BN の弚れらは少しずつ低 下していく. $B_{\max } 175$ Gauss 以下では THT-III A-BN の 推力・比推力は THT-III-BN の㫕れらより大きい . THTIII A-BN では THT-III-BN に比べて加速チャンネル出口 付近に極度に急峻な磁場が形成されているため, 電離領域 (イオンの生成領域) がより狭く，より出口付近にあり加速 チャンネル壁面でのイオン損失は少ないが , 生成イオンの 加速か磁力線の湾曲の影響を強く受け, 磁場強度の増加と 共にイオン軌道が变化し, すなわちイオン発散角が少し大 


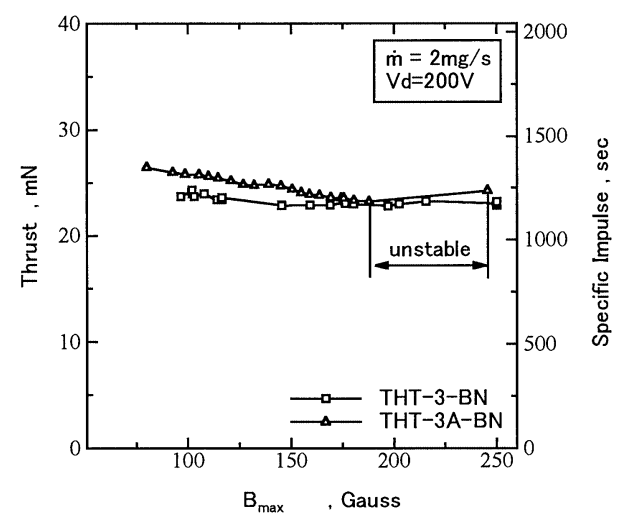

第 6 図 推力・比推力と磁束密度 $B_{\max }$ の関係 (推進剂質量流量 : $2 \mathrm{mg} / \mathrm{s}$; 放電電流 : $200 \mathrm{~V}$, THT-III-BN と THT-III A-BN の比較)

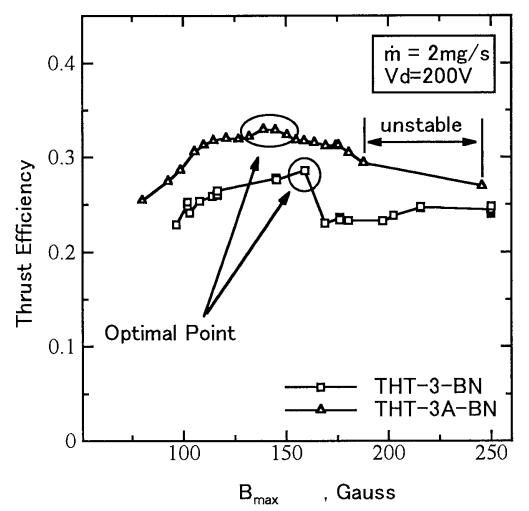

第 7 図 推進効率と磁束密度 $B_{\max }$ の関係 (推進剂質量流量 : $2 \mathrm{mg} / \mathrm{s}$; 放電電流 : $200 \mathrm{~V}$, THT-III-BN と THT-III A-BN の比較)

きくなると推定される .こうして , 加速チャンネル出口付 近の磁場を強くすることによって，効率よいイオン生成が 可能であるが，イオン加速・噴出過程においては磁力線の 湾曲など詳細な磁場構造を考慮した产の最適化が必要であ ると考えられる .

推進効率と磁束密度 $B_{\max }$ の関係を第 7 図に示す. THTIII-Mullite の推進効率は $B_{\max } 160$ Gauss 以下の作動にお いて THT-III-BN の弚れより小さく，加速チャンネル壁の 材質としてムライトより BN か望ましいことがわかった . 磁場形状の違いによる変化では, THT-III A-BNがTHTIII-BN と比較して高い推進効率を示している. THT-III ABN では $B_{\max }$ 110〜175 Gauss において比較的高い推進効 率が得られ，光の範囲よりも磁束密度が大きくても小さく ても効率は低下している .これは弱磁場域では放電電流が 大きいため，強磁場域では推力が低下するためである．ま た，THT-III A-BN は THT-III-BN のような急激な放電電 流の増加が生じないため, 最適作動点近傍のフラットな領 域か比較的広い，実機として使用する際に磁場コイル電流 の制御が容易であるというメリットを備えている .

以上の結果より，加速チャンネル壁の材質が推進性能に与 える影響は次のように解釈できる．ムライトを用いた場合 の放電電流が BN を用いた場合の兰れより弱磁場域で大き
い理由は，推力（イオン電流に相当）がチャンネル壁の材質 に依存しないことより，逆流電流 (陰極から陽極へ流れる電 子電流, 放電電流は二の逆流電流と放出されるイオン電流 を中和するための電子電流の和である) が大きいためと考え られる .この逆流電流はチャンネルバルク空間における電子 電流とチャンネル壁のごく近傍における電子電流に分ける ことができるが, 後者の伝導性 (Near Wall Conductivity) にチャンネル材質が大きな影響を及ぼしていると推測され る.ムライトは BN と比較して熱伝導率が悪いため) ( ライトと BN の熱伝導率は光れ午れ $0.012 \mathrm{cal} / \mathrm{cm} \cdot \mathrm{s} \cdot{ }^{\circ} \mathrm{C}$ と $0.18 \mathrm{cal} / \mathrm{cm} \cdot \mathrm{s} \cdot{ }^{\circ} \mathrm{C}$ である) チャンネル壁表面が高温に加熱 され, 2 次電子放出係数 (電子温度 $20 \sim 40 \mathrm{eV}$ の場合, 常 温では両材料の係数は 1 前後であるが, 融点近くで光れら は爆発的に大きくなる) が上昇する. 2 次電子放出が盛ん に行われることにより壁近傍のシース状態か変化し，壁近 傍において高い電気伝導がなされ，逆流電流が大きくなる と推定される (もしくは，ムライトの融点 $\left(1,400^{\circ} \mathrm{C}\right)$ は $\mathrm{BN}$ の兰れ $\left(2,200^{\circ} \mathrm{C}\right)$ より十分低いので, チャンネル壁面 はほとんど溶融状態にあり, 電気伝導性か増加すると推測 される) .

こうして, 加速チャンネルのセラミックスの材質は放電電 流特性に影響を与え, チャンネル内の磁場形状は推力特性 に影響を与える.放電電流を小さく抑えるにはチャンネル壁 として BN を使用し, 磁場形状としてはチャンネル出口付 近に急峻な強い磁場を印加し陽極付近の磁場を弱くするこ とによって，より高い推進性能が得られることがわかった .

3.2 放電電圧による変化 前節 3.1 の結果より, 最も良 好な推進性能が得られたスラスタ THT-III A-BNを用いた。 推進剂質量流量は一定で, $2 \mathrm{mg} / \mathrm{s}$ である.まず，放電電圧 200,300, 400, $500 \mathrm{~V}$ の 4 つの值において推進効率を最大 にする最適磁束密度 $B_{\mathrm{opt}}$ を調べた。炎の結果，光れらの 值はすべて 150 Gauss 付近にあったので磁束密度を $B_{\max }$ 150 Gauss に固定し, 放電電圧を $80 \sim 200 \mathrm{~V}$ まで変化させ た .すなわち, 推進昘流量一定のとき最適磁束密度の放電 電圧依存性は弱い，弚の放電電圧に関する作動特性を第 8 図に示す。

第 8 図 (a) より, 放電電圧 $100 \mathrm{~V}$ 以下の領域では放電電 圧の増加と共に放電電流が急上昇する .これは放電電圧の 上昇に伴って推進剂の電離が急激に進むためである. 放電 電圧 100 $130 \mathrm{~V}$ の領域では電流増加率が負になる . これ は放電電圧の上昇と共に逆流電流が低下する (チャンネル バルク空間における電気伝導 (電子生成・拡散) 状態か変 化する) ためと考えられる . 放電電圧 130～500 V の領域 では放電電流值の変化はほとんどなく，ほぼ定電流特性を 示している .このとき推進剤はほぼ完全電離状態にあると 推測され，スラスタはこの放電電圧領域にて運転される .

推力, 比推力は第 8 図 (b) より, 放電電圧の増加と共に 上昇する .これは放電電圧 $100 \mathrm{~V}$ 以下の領域ではイオンの 活発な生成と共にイオンの加速が始まり, 放電電圧 $100 \mathrm{~V}$ 以上の領域では実質的なイオンの加速電圧が上昇するため と考えられる. 本作動範囲内では最大推力 $45 \mathrm{mN}$, 比推力 


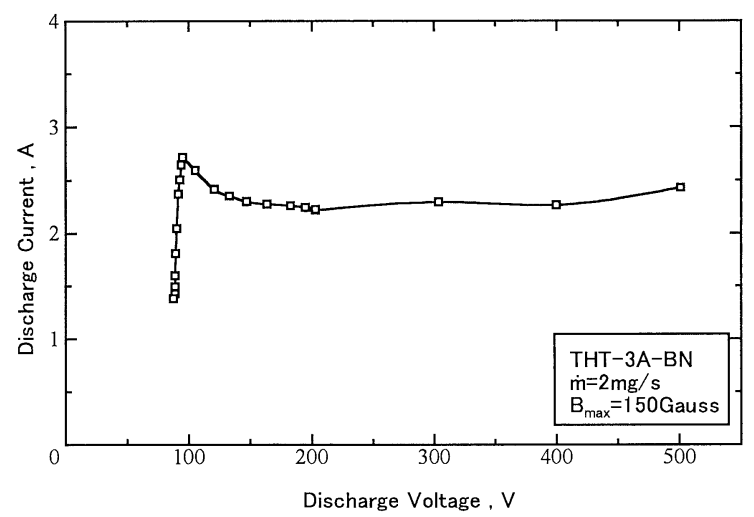

(a) 放電電流と放電電圧の関係

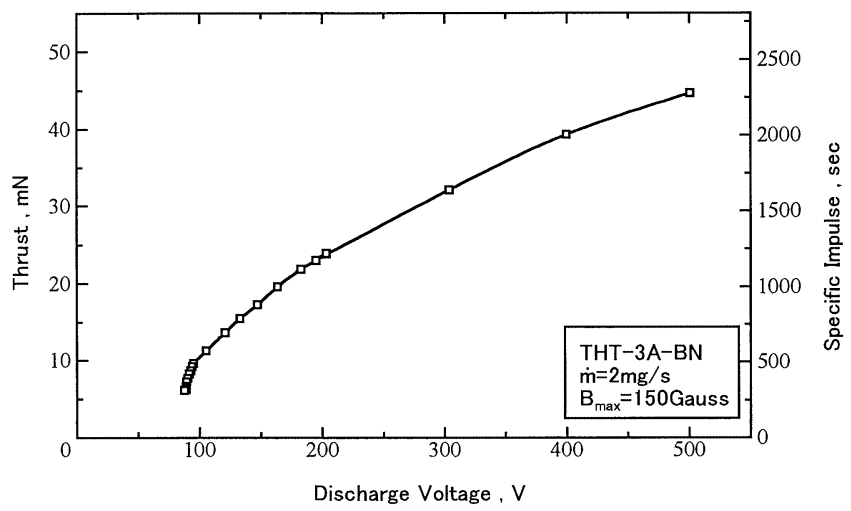

(b) 推力 ・比推力と放電電圧の関係

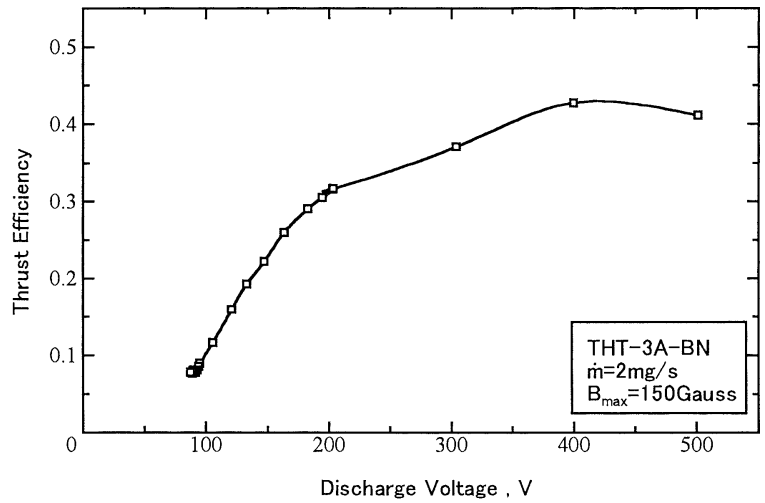

(c) 推進効率と放電電圧の関係

第 8 図 THT-III A-BN の作動特性（推進斉質量流量 : $2 \mathrm{mg} / \mathrm{s}$; 磁束 密度 $B_{\max }$ : 150 Gauss)

2,250 秒が得られた . 理想的な静電加速においては加速電 圧の平方根に推力 ・比推力が比例する（イオン速度が比例 する) が, 本推力・比推力特性は零から $80 \mathrm{~V}$ 程度ずれて この電圧を差し引いた值の平方根に比例することがわかる. すなわち， $80 \mathrm{~V}$ 程度はイオンの加速には寄与せず, 両電極 の電圧降下, 電離やチャンネル壁面損失などに相当すると 推定される.

第 8 図 (c) より, 推進効率は放電電圧の上昇と共に増加 し, 放電電圧 $400 \mathrm{~V}$ において最も高い推進効率が得られる が, 弚の後 $500 \mathrm{~V}$ にかけて緩やかに低下している.これは 放電電圧 $500 \mathrm{~V}$ の作動において僅かに放電電流が増加する

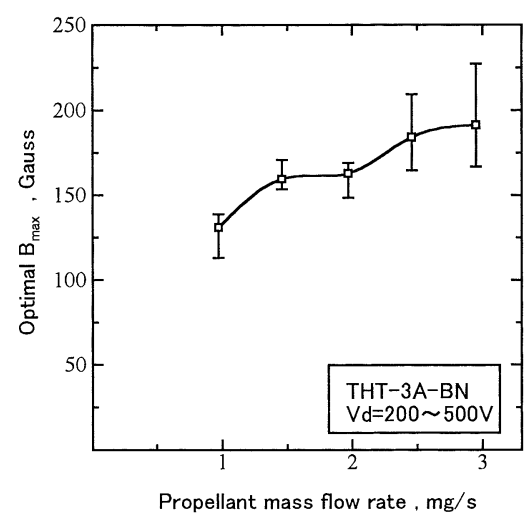

第 9 図 THT-III A-BN の最適磁束密度と推進剂質量流量の関係 (放 電電圧 : 200 500 V)

ためである .この放電電流の増加は 2 価電離イオンの増加 によると推定される . ホールスラスタの噴出プルーム中に は多価電離イオンが含まれていることが観測されており， 兴の割合は放電電圧の上昇と共に増加すると考えられる13)。 推進剂キセノンを 2 価電離させるには高い電離エネルギー を必要とし, エネルギー損失が放電電圧の増加と共に増え る.こうして，推進効率は放電電圧に関して極大值をもつ と推定される . 放電電圧 $400 \mathrm{~V}$ のとき比推力 2,000 秒, 推 進効率 $42.7 \%$ が達成された .この性能は SPT などの諸外 国のホールスラスタと比較しても遜色ないものである .

なお，ムライト系セラミックスを加速チャンネル壁に使 用した THT-III-Mullite において放電電圧を $200 \mathrm{~V}$ 以上に 設定すると, チャンネル壁の赤熱, 溶融, 割れなどの現象が 生じた .もちろん, チャンネル壁に BN を用いた場合はこ のような現象は起きなかった .これはムライト系セラミック スの熱伝導性と耐熱性の悪さが原因であると推定され, 前 節 3.1 のチャンネル壁の材質に関する解釈を裏付けるもの である .

3.3 推進剂流量の影響 推進剂質量流量を $1 \sim 3 \mathrm{mg} / \mathrm{s}$, 放電電圧を 200〜 $500 \mathrm{~V}$ の範囲で変化させて作動実験を行っ た . 磁場の強さはすべて最適磁束密度 $B_{\mathrm{opt}}$ に設定された . すなわち, ある推進剂流量, 放電電圧のもとで磁気コイル に流す電流を変化させながら推進効率を最大にするコイル 電流值を調べ, 兴のコイル電流において放電電流・推力の 測定を行った。

最適磁束密度と推進剂質量流量の関係を第 9 図に示す. 縦軸の最適磁束密度はすべての放電電圧における平均值を 表している. 推進剂流量の増加に伴い最適磁束密度は増加 する .これは推進剂流量の増加と共に加速チャンネル内の 中性粒子密度が大きくなり電子-中性粒子衝突による電子拡 散が盛んになり，逆流電流の増加を抑えるために，より強 い磁場が必要になるためと考えられる．

放電電流と推進剂質量流量の関係を第 10 図に示す . 縦軸 の放電電流はすべての放電電圧における平均値を表してい る.推進剂流量の上昇に伴い放電電流も上昇し，ほぼ比例 関係にあることがわかる . 


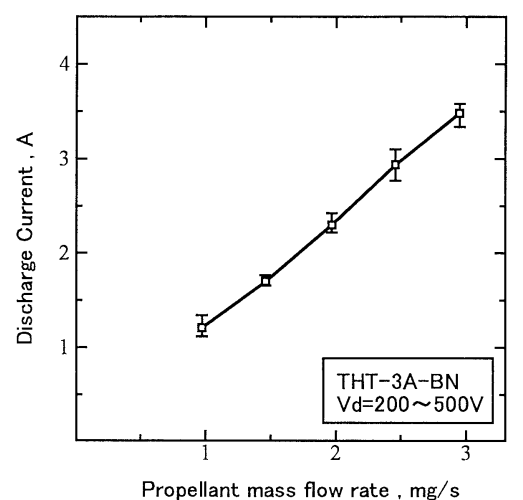

第10図 THT-III A-BN の放電電流と推進剂質量流量の関係 (放電 電圧 : $200 \sim 500 \mathrm{~V}$; 磁束密度 $B_{\max }$ : 最適磁束密度 $B_{\mathrm{opt}}$ )

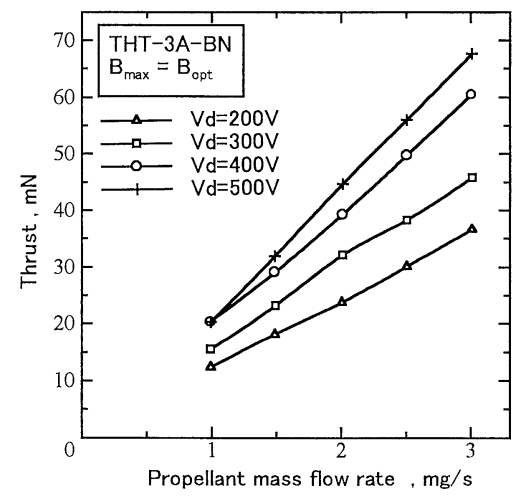

(a) 推力

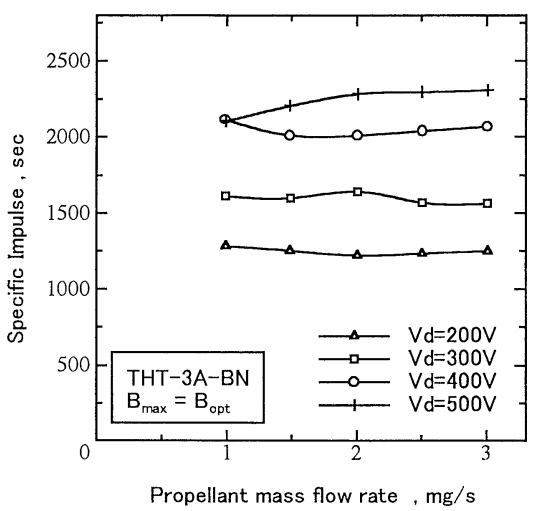

(b) 比推力

第11 図 THT-III A-BN の推力, 比推力と推進斉質量流量の関係 (放 電電圧 : $200 \sim 500 \mathrm{~V}$; 磁束密度 $B_{\max }$ : 最適磁束密度 $B_{\mathrm{opt}}$ )

推力 , 比推力と推進剂質量流量の関係を第 11 図に示す . 推力は推進剂流量にほぼ比例している .一方, 比推力は放 電電圧 200〜400V の範囲では推進斉流量の影響を受けず ほぼ一定である . 本作動条件において推力は $12 〜 68 \mathrm{mN}$ ， 比推力は $1,200 〜 2,300$ 秒の広い範囲がカバーされる.これ より，推進斉流量の変化がイオンの生成・加速に及ぼす影響 は少ないと推定される . 放電電圧 $500 \mathrm{~V}$ においてのみ, 推 進闵流量が小さいとき比推力が低下する傾向がある．これ は放電電圧 (イオンの加速電圧) の上昇に伴って加速チャ ンネル内のプラズマ密度が減少し, 低推進阂流量では推進

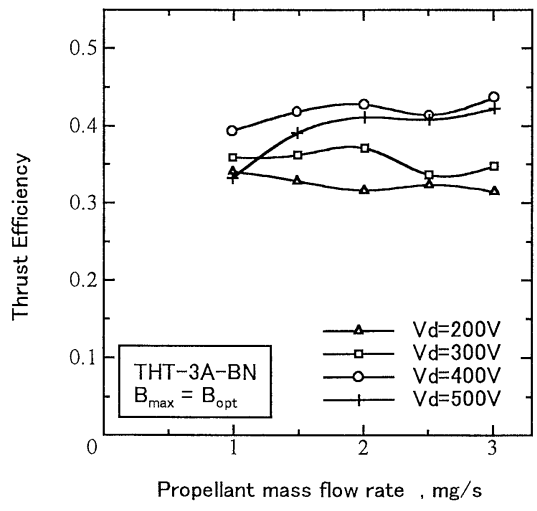

第 12 図 THT-III A-BN の推進効率と推進斉質量流量の関係 (放電 電圧 : $200 \sim 500 \mathrm{~V}$; 磁束密度 $B_{\max }$ : 最適磁束密度 $B_{\mathrm{opt}}$ )

剂の電離衝突頻度が極度に低下し，推進剂の利用効率が低 くなったと推察される。

推進効率と推進剂質量流量の関係を第 12 図に示す. 放 電電圧 200〜 400 Vでは推進効率は推進阂流量の影響をあ まり受けずほぼ一定で，30〜45\%の範囲にある . 放電電圧 $500 \mathrm{~V}$, 低推進剂流量では推進効率が低下する.

こうして，ホールスラスタは高性能を維持できる作動可 能な推進斉流量の範囲が広いことがわかった . ホールスラ スタの放電電流は推進剂流量とほぼ比例するため，投入電 カ一定の条件のもとで作動を行う際にも，推進斉流量を調 節することで放電電流值を変化させ, 光の結果放電電圧を 樣々な值に設定できる。つまり，推進阂流量を大きく(放電 電流を大きく）放電電圧を小さく設定して作動させると高 推力モード, 推進阂流量を小さく（放電電流を小さく）放 電電圧を高く設定して作動させると高比推力モードという ように, ミッションに応じて柔軟な使い分けが可能となる。

3.4 入力電力による変化 第 11 図と第 12 図を書き直 し，横軸に投入電力をとり整理したものを第 13 図と第 14 図に示す. 推力と比推力は共に推進剂流量一定では投入電 力の増加に伴って単調に増加するが, 高電力作動において は光の上昇割合は鈍る . 推進効率も同樣な傾向を示し, 特 に高電力においては効率の低下か現れる．すなわち, 過度 の電力投入は電力損失を招くことがわかる. 結果として, 本 作動範囲は投入電力 250 〜 $1,800 \mathrm{~W}$ になった .

\section{4. ま と め}

低電カホールスラスタ THT-III シリーズ (THT-IIIMullite, THT-III-BN , THT-III A-BN) の作動実験を行 い, 加速チャンネル壁の材質, チャンネル内の磁場の形状 · 強さか性能特性に与える影響を調べた . 放電電圧と推進剂 キセノンの質量流量を变化させ放電電流と推力を測定し， 比推力と推進効率を評価した .

基本作動特性を調べた結果，推進剂流量と放電電圧一定 のもとでは推進効率を最大にする加速チャンネル内の最適 磁場強度が存在した . 弚の值の放電電圧への依存性は小さ いが, 推進斉流量の増加と共に大きくなった . 推進㶡流量 


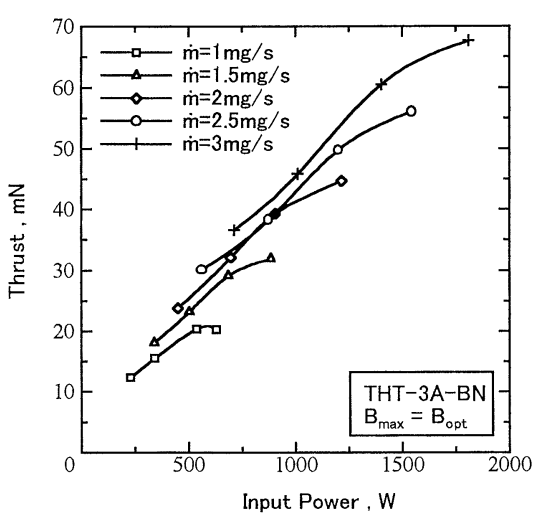

(a) 推力

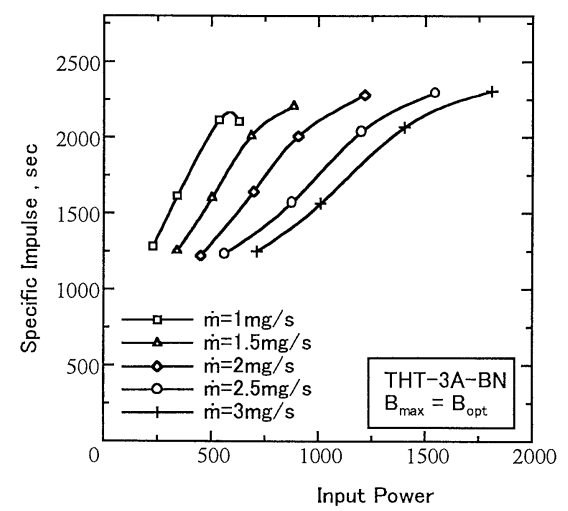

(b) 比推力

第13 図 THT-III A-BN の推力, 比推力と投入電力の関係 (推進剂 質量流量 : $1 \sim 3 \mathrm{mg} / \mathrm{s}$; 磁束密度 $B_{\max }$ : 最適磁束密度 $B_{\mathrm{opt}}$ ）

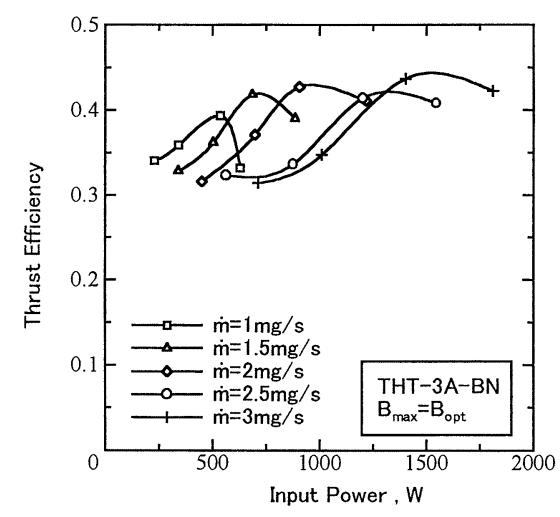

第14図 THT-III A-BN の推進効率と投入電力の関係 (推進剂質量 流量 : $1 \sim 3 \mathrm{mg} / \mathrm{s}$; 磁束密度 $B_{\max }$ : 最適磁束密度 $B_{\mathrm{opt}}$ ）

一定で最適磁場の印加時, 放電電圧の上昇と共に推力, 比 推力, 推進効率は増加した .一方, 放電電圧 130 〜 $500 \mathrm{~V}$ の 範囲において, 放電電流はほぼ定電流特性を示した。推進 剂質量流量 1 3 mg/s の範囲で変化させてもこの作動特性 の傾向はほとんど変わらなかった . このとき投入電力は 250
〜 $1,800 \mathrm{~W}$ となり，推進効率 $30 \%$ 以上を維持することがで きた .

加速チャンネル壁の材質に BN を用いるとムライトを用 いた場合に比べて放電電流が小さく抑えられ，さらにチャ ンネル内の磁場をチャンネル出口付近で強く陽極付近で弱 くし，すなわち急峻な磁場を印加したとき高推力が得られ， 推進性能が向上することがわかった .これらの効果は光れ 光れ, BN とムライトの熱伝導, 2 次電子放出特性に関係し たチャンネル壁近傍の電気伝導現象の差異と，磁場形状の 違いによるチャンネルバルク空間でのイオン生成・加速過 程の差異によって説明することが可能であった . 代表的な 性能として, 推進剂質量流量 $2 \mathrm{mg} / \mathrm{s}$, 放電電圧 $400 \mathrm{~V}$, 放 電電流 $2.27 \mathrm{~A}$, 投入電力 $908 \mathrm{~W}$ 時に, 推力 $39.3 \mathrm{mN}$, 比 推力 2,000 秒, 推進効率 $42.7 \%$ が得られ, SPT などの諸外 国のホールスラスタと比較しても遜色ないものであった .

\section{参 考 文 献}

1) Kim, V., Popov, G., Arkhipov, B., Murashko, V., Gorshkov, O., Koroteyev, A., Garkusha, V., Semenkin, A. and Tverdokhlebov, S.: Electric Propulsion Activity in Russia, 27th IEPC, Pasadena, IEPC Paper 01-005, 2001.

2) Dunning, J. W., Benson, S., Jr. and Oleson, S.: NASA's Electric Propulsion Program, 27th IEPC, Pasadena, IEPC Paper 01-002, 2001.

3) Cadiou, A., Gelas, C., Darnon, F., Jolivet, L. and Pillet, N.: An Overview of the CNES Electric Propulsion Program, 27th IEPC, Pasadena, IEPC Paper 01-008, 2001.

4) Kadomtsev, B. B. and Shafranov, V. D.: Reviews of Plasma Physics, Vol. 21, Kluwer Academic/Plenum Publishers, New York, 2000, pp. 203-391.

5) Zhurin, V. V., Kaufman, H. R. and Robinson, R. S.: Physics of Closed Drift Thrusters, Proceedings of the 25th IEPC, Cleveland, Vol. 2, 1997, IEPC Paper 97-191, pp.1175-1182.

6) Kim, V.: Main Physical Features and Processes Determining the Performance of Stationary Plasma Thrusters, J. Propul. Power, 14 (1998), pp.736-743.

7) Prioul, M., Bouchoule, A., Roche, S., Magne, L., Pagnon, D. and Lasgorceix, P.: Insights on Physics of Hall Thrusters through Fast Current Interruptions and Discharge Transients, 27th IEPC, Pasadena, IEPC Paper 01-059, 2001.

8) Komurasaki, K. and Arakawa, Y.: Hall Current Ion Thruster Performance, J. Propul. Power, 8 (1992), pp. 1212-1216.

9) Tahara, H., Mitsuo, K., Goto, D., Yasui, T. and Yoshikawa, T.: Operating Characteristics of Low Power Hall Thrusters, 22nd International Symposium on Space Technology and Science, Morioka, ISTS Paper 2000-b-36p, 2000.

10) Tahara, H., Nikai, Y., Yasui, T. and Yoshikawa, T.: Hall Thruster Research at Osaka University, AIAA Paper 99$2570,1999$.

11) Tahara, H., Goto, D., Yasui, T. and Yoshikawa, T.: Thrust Performance and Plasma Characteristics of Low Power Hall Thrusters, 27th IEPC, Pasadena, IEPC Paper 01-042, 2001.

12）田原弘一, 白崎篤司，マヌエルマルチネスサンチェス : ホールス ラスタ流れ場の一次元計算，日本航空宇宙学会論文集，投稿中。

13) Gallimore, A. D.: Near- and Far-Field Characterization of Stationary Plasma Thruster Plumes, J. Spacecraft Rockets, 38 (2001), pp. 441-453. 